\title{
Rhodovulum iodosum sp. nov. and Rhodovulum robiginosum sp. nov., two new marine phototrophic ferrous-iron-oxidizing purple bacteria
}

\author{
Kristina L. Straub, ${ }^{1}$ Frederick A. Rainey ${ }^{2,3}$ and Friedrich Widdel ${ }^{1}$ \\ Author for correspondence: Kristina L. Straub. Tel: +49421 2028 736. Fax : +49421 2028580. \\ e-mail:kstraub@mpi-bremen.de
}

\footnotetext{
1 Max-Planck-Institut für Marine Mikrobiologie, Celsiusstr. 1, D-28359 Bremen, Germany

2 Deutsche Sammlung von Mikroorganismen und Zellkulturen $\mathrm{GmbH}$, Mascheroder Weg $1 b$, D-38124 Braunschweig, Germany

3 Department of Microbiology, Louisiana State University, Baton Rouge, LA 70803, USA
}

\begin{abstract}
Two new strains of marine purple bacteria, $\mathrm{N1}^{\top}$ and $\mathrm{N2}^{\top}$, were isolated from coastal sediment of the North Sea (Germany) with ferrous iron as the only electron donor for anoxygenic photosynthesis. The isolates are the first saltdependent, ferrous-iron-oxidizing purple bacteria characterized so far. Analysis of 165 rRNA gene sequences revealed an affiliation with the genus Rhodovulum, which until now comprises only marine species. The sequence similarity of both strains was $\mathbf{9 5 \cdot 2} \%$, and their closest relative was Rhodovulum adriaticum. Like all known Rhodovulum species, the new strains had ovoid to rod-shaped cells, contained bacteriochlorophyll a and carotenoids of the spheroidene series, and were able to oxidize sulfide and thiosulfate. Like Rhodovulum adriaticum, both strains were unable to assimilate sulfate; for growth they needed a reduced sulfur source, e.g. thiosulfate. In contrast to the new strains, none of the known Rhodovulum species tested was able to oxidize ferrous iron or iron sulfide. In growth experiments, strains $\mathrm{N1}^{\top}$ and $\mathrm{N2}^{\top}$ oxidized 65 and $95 \%$, respectively, of the ferrous iron supplied. Electron diffraction analysis revealed ferrihydrite as the main product of ferrous iron oxidation. In addition, traces of magnetite were formed. Strains $\mathrm{N}^{\top}{ }^{\top}$ (= DSM 12328') and N2 ${ }^{\top}$ (= DSM 12329') are described as Rhodovulum iodosum sp. nov. and Rhodovulum robiginosum sp. nov., respectively.
\end{abstract}

Keywords: ferrous iron oxidation, purple bacteria, Rhodovulum iodosum, Rhodovulum robiginosum

\section{INTRODUCTION}

The utilization of ferrous iron as electron donor for anoxygenic photosynthesis was first recognized in crude enrichment cultures with iron-rich anaerobic freshwater and marine mud samples. Of subsequently isolated pure cultures, only those from freshwater habitats showed good growth on ferrous iron and were therefore characterized in detail (Ehrenreich \& Widdel, 1994; Heising \& Schink, 1998; Widdel et al., 1993). Although marine enrichment cultures oxidized ferrous iron as efficiently as the freshwater enrichment cultures, marine isolates developed only poorly; these isolates were not preserved.

The EMBL accession numbers for the $16 \mathrm{~S}$ rDNA sequences determined in this study are $\mathrm{Y} 15011$ and $\mathrm{Y} 15012$ for strains $N 1^{\top}$ and $N 2^{\top}$, respectively.
Coastal sediments often contain large pools of ferric iron, which may function as an important electron acceptor for the oxidation of organic carbon (Aller $e t$ al., 1986; Canfield et al., 1993a). It has been suggested that at high rates of ferric iron reduction, ferrous iron occurs in the upper millimetres of marine sediments (Canfield et al., 1993b; Thamdrup et al., 1994). Hence, the simultaneous occurrence of light and ferrous iron is likely so that the latter may serve as electron donor for anoxygenic phototrophs. Ferrous iron oxidation by anoxygenic phototrophs is understandable in terms of energetics. The $\mathrm{Fe}(\mathrm{III}) / \mathrm{Fe}(\mathrm{II})$ redox pair in bicarbonate-containing environments has an $E_{0}^{\prime}$ around $+0 \cdot 2 \mathrm{~V}$. Hence, electron transfer to the anoxygenic photosystem with a midpoint potential around $+0.45 \mathrm{~V}$ is feasible (Widdel et al., 1993). Another naturally widespread redox-active metal is manganese. Similar to ferrous iron, manganese(II) may also occur 
in the surface layers of sediments (Thamdrup et al., 1994). However, according to thermodynamic data, manganese(II) is unlikely to serve as electron donor for anoxygenic phototrophs in environments with $\mathrm{pH}$ values below 9, since the redox potential of the $\mathrm{Mn}(\mathrm{IV}) / \mathrm{Mn}$ (II) couple is around $+0.6 \mathrm{~V}$ and hence too positive (Brookins, 1988).

For comparative studies on ferrous-iron-oxidizing phototrophic bacteria we started enrichment cultures to obtain marine counterparts of the known freshwater isolates. Here we describe the isolation, physiological features and phylogenetic affiliation of two new marine species for which the names Rhodovulum iodosum and Rhodovulum robiginosum are proposed. Furthermore, the new isolates are compared to described Rhodovulum species.

\section{METHODS}

Source of bacteria. Sediment for enrichment cultures was collected from the mud flat of the Jadebusen (North Sea, Germany) at four different sites. Rhodovulum adriaticum DSM 2781 ${ }^{\mathrm{T}}$, Rhodovulum euryhalinum DSM $4868^{\mathrm{T}}$ and Rhodovulum sulfidophilum DSM $1374^{\mathrm{T}}$ were obtained from the Deutsche Sammlung von Mikroorganismen und Zellkulturen (DSMZ), Braunschweig, Germany.

Media and growth conditions. Techniques for preparation of media and cultivation of phototrophic bacteria under anoxic conditions have been described elsewhere (Widdel \& Bak, 1992). For the present study, artificial seawater medium was used which contained (per litre distilled water): $0.4 \mathrm{~g}$ $\mathrm{KH}_{2} \mathrm{PO}_{4}, 26.4 \mathrm{~g} \mathrm{NaCl}, 0.25 \mathrm{~g} \mathrm{NH}_{4} \mathrm{Cl}, 6.8 \mathrm{~g} \mathrm{MgSO}_{4} .7 \mathrm{H}_{2} \mathrm{O}$, $5.7 \mathrm{~g} \mathrm{MgCl}_{2} .6 \mathrm{H}_{2} \mathrm{O}, 1.5 \mathrm{~g} \mathrm{CaCl}_{2} .2 \mathrm{H}_{2} \mathrm{O}, 0.66 \mathrm{~g} \mathrm{KCl}^{2}$ and $0.09 \mathrm{~g}$ $\mathrm{KBr}$. After autoclaving and cooling under an atmosphere of $\mathrm{N}_{2} / \mathrm{CO}_{2}(90: 10, \mathrm{v} / \mathrm{v}), 30 \mathrm{ml} \mathrm{NaHCO}_{3}$ solution $\left(84 \mathrm{~g} \mathrm{l}^{-1}\right.$, autoclaved under $\mathrm{CO}_{2}$ ), vitamins, EDTA-chelated mixture of trace elements, and selenite and tungstate solution (Widdel \& Bak, 1992) were added. The $\mathrm{pH}$ was adjusted to 6.9. Unless indicated otherwise, $0.5 \mathrm{mM} \mathrm{Na}_{2} \mathrm{~S}_{2} \mathrm{O}_{3}$ was added as a source of reduced sulfur from a filter-sterilized stock solution (1 M).

$\mathrm{FeSO}_{4}$ was added to culture medium from a $1 \cdot 0 \mathrm{M}$ anoxic stock solution; upon the addition of $\mathrm{FeSO}_{4}$ to the medium (final concentration $10 \mathrm{mM}$ ), a white precipitate, most likely consisting of ferrous carbonate and ferrous phosphate, formed. An anoxic suspension of FeS was prepared as described previously (Ehrenreich \& Widdel, 1994). For experiments with free sulfide, sodium sulfide was added to the media from an anoxic autoclaved stock solution $(1 \mathrm{M})$ to the final concentrations indicated. Culture tubes and bottles were incubated horizontally on a Plexiglas plate and illuminated with two tungsten lamps $(25 \mathrm{~W})$ installed above and below the cultures at a distance of $30 \mathrm{~cm}$. Enrichment cultures were incubated at $20^{\circ} \mathrm{C}$ and gently shaken every other day to allow even distribution of bacteria and ferrous iron minerals.

Utilization of other compounds as electron donors for photosynthetic growth was tested in media without $\mathrm{FeSO}_{4}$ (except for $7.5 \mu \mathrm{M} \mathrm{FeSO}$ from trace element solution). Ferrous sulfide, free sulfide, propionate, butyrate, valerate, caproate, caprylate, methanol, ethanol, pyruvate, glucose and fructose were supplied at a final concentration of $2 \mathrm{mM}$. The final concentration of yeast extract and Casamino acids was $0.5 \mathrm{~g} \mathrm{l}^{-1}$. All other compounds were added at a final concentration of $4 \mathrm{mM}$.

Isolation. Pure cultures were obtained via repeated agar dilution series (Widdel \& Bak, 1992) prepared with a slight modification: to $3 \mathrm{ml} 3 \%(\mathrm{w} / \mathrm{v})$ agar molten in a test tube, $0.11 \mathrm{ml}$ of a $1 \mathrm{M} \mathrm{FeSO}_{4}$ solution and $8 \mathrm{ml}$ prewarmed medium were subsequently added. $\mathrm{FeSO}_{4}$ was supplied as the only electron donor. Purity was verified microscopically after incubation of isolates in medium with yeast extract $\left(0.5 \mathrm{~g} \mathrm{l}^{-1}\right)$, pyruvate $(2 \mathrm{mM})$, glucose $(1 \mathrm{mM})$ or acetate $(5 \mathrm{mM})$. In addition, the homogeneity of colonies in agar dilutions was checked.

Analytical methods. Ferrous iron was quantified spectrophotometrically at $510 \mathrm{~nm}$ after chelation with $2 \mathrm{mM} \mathrm{o-}$ phenanthroline in $0.7 \mathrm{M}$ sodium acetate buffer, $\mathrm{pH} 5$, in a test volume of $1 \mathrm{ml}$ (modified from Fachgruppe Wasserchemie, 1991). Immediately before withdrawing samples, cultures were agitated to disperse iron precipitates homogeneously. Samples were taken with anoxic syringes and were immediately acidified with $\mathrm{HCl}$ (final concentration $1 \mathrm{M}$ ). The concentration of ferric iron was determined in the same way after reduction with $0.28 \mathrm{M}$ hydroxylammonium chloride; the ferrous iron concentration determined before reduction was subtracted.

The type of photosynthetically produced ferric iron was identified by electron diffraction analysis. Two millilitres of spent medium, with ferric iron produced during photoautotrophic growth on ferrous iron, was washed five times with $25 \mathrm{ml}$ distilled water to remove medium components; then a drop of the ferric iron suspension was placed onto a Formvar-carbon-coated copper grid and air-dried. Selected area diffraction was carried out with a Zeiss EM10 electron microscope to identify the ferric iron and to determine its degree of crystallinity. The analysis was carried out by Marianne Hanzlik, Munich, Germany.

Sulfate was determined on a Sykam (Gilching) ion chromatograph according to Bak et al. (1991).

Carotenoids were extracted from cell pellets of acetategrown cultures $(10 \mathrm{ml})$ by using $100 \%$ acetone $(3 \mathrm{ml})$ and sonication (Sun et al., 1991). The carotenoid composition was determined by HPLC analysis according to Overmann et al. (1992); the column was Spherisorb ODS-2, $5 \mu \mathrm{m}$, and the eluent was acetonitrile/methanol/2-propanol $(85: 10: 5)$. Carotenoids of Rhodovulum sulfidophilum were extracted for comparison.

16S rDNA sequence determination, phylogenetic analyses and DNA base composition. Genomic DNA extraction, PCR amplification of the $16 \mathrm{~S}$ rDNA and sequencing of the PCR products were carried out as described previously (Rainey et al., 1996). Sequence reaction products were electrophoretically separated using a model 373A automated sequencer (Applied Biosystems). The ae2 editor (Maidak et al., 1994) was used to align the 16S rDNA sequences obtained in this study against the previously determined $16 \mathrm{~S}$ rDNA sequences of Rhodovulum and Rhodobacter species available from the public databases. The method of Jukes \& Cantor (1969) was used to calculate evolutionary distances. Phylogenetic dendrograms were generated using various treeing algorithms contained in the PHYLIP package (Felsenstein, 1993). The phylogenetic dendrogram shown in Fig. 1 was reconstructed from evolutionary distances using the algorithm of DeSoete (1983).

The $\mathrm{G}+\mathrm{C}$ content of the DNA was determined by HPLC (DSMZ). 
Two new Rhodovulum species

Strain accession numbers. Strains $\mathrm{N} 1^{\mathrm{T}}$ and $\mathrm{N} 2^{\mathrm{T}}$ are deposited at the DSMZ under accession numbers DSM $12328^{\mathrm{T}}$ and DSM $12329^{\mathrm{T}}$, respectively. The strain designations and accession numbers of the reference strains used in the phylogenetic analyses are as follows: Rhodobacter blasticus ATCC 33485' D16429; Rhodobacter capsulatus ATCC $11166^{\mathrm{T}}$, D13474; Rhodobacter sphaeroides IFO 12203, D16425; Rhodobacter veldkampii ATCC 35703 ${ }^{\mathrm{T}}$, D16421; Rhodobacter sp. strain SW2, X78717; Rhodovulum adriaticum DSM 2781 ${ }^{\mathrm{T}}$, D16418; Rhodovulum euryhalinum DSM 4868 ${ }^{\mathrm{T}}$, D13479; Rhodovulum strictum MB-G2, D16419; Rhodovulum sulfidophilum DSM 1374 ${ }^{\mathrm{T}}$, D16423; Roseobacter denitrificans LMG 4218, X69159.

\section{RESULTS AND DISCUSSION}

\section{Enrichment and isolation}

Artificial seawater medium supplied with $10 \mathrm{mM}$ $\mathrm{FeSO}_{4}$ as the only electron donor was inoculated with marine sediment samples from four different sites of the Jadebusen. Enrichment cultures were incubated horizontally in the light at $20^{\circ} \mathrm{C}$. Rusty patches developed in particular on the sediment side which was illuminated from below, and after 3-4 weeks incubation the entire lower glass wall was covered by a rusty layer. After subsequent transfer of all four enrichment cultures to fresh $\mathrm{FeSO}_{4}$-containing medium (inoculum size $5-10 \%, \mathrm{v} / \mathrm{v}$ ), the rate and extent of the ferrous iron oxidation decreased significantly. However, when transfers were made in the presence of a reduced sulfur source such as $0.5 \mathrm{mM}$ FeS or $0.5 \mathrm{mM}$ $\mathrm{Na}_{2} \mathrm{~S}_{2} \mathrm{O}_{3}$ the capacity for ferrous iron oxidation continued in all subcultures, and the precipitated ferrous iron minerals turned completely rusty within 2 weeks. Obviously, sulfate which was always present in the medium could not be used as sulfur source. Continued cultivation was therefore only possible when a reduced sulfur source was routinely added to the media. Because sample material was obtained from the same area as in the former study (Widdel et al., 1993), one might speculate whether the poor growth of the formerly obtained isolates was due to the lack of a reduced sulfur source.

Agar dilutions with $10 \mathrm{mM} \mathrm{FeSO}_{4}$ as the only electron donor were inoculated from the eighth subcultures. After 3 weeks incubation in the light, opaque rustyorange colonies had formed amongst a variety of small red-coloured colonies. With the rusty-orange colonies subsequent agar dilution series were inoculated; from these 10 colonies were isolated and transferred to liquid media. All isolates were able to oxidize ferrous iron in the light; in controls in the dark no oxidation of ferrous iron occurred. Two isolates, strains $\mathrm{N}^{\mathrm{T}}$ and $\mathrm{N} 2^{\mathrm{T}}$, which formed rusty deposits of distinct consistency were chosen for further characterization. When strain $\mathrm{N}^{\mathrm{T}}$ was grown without agitation, the ferric iron produced formed a solid layer sticking firmly to the glass wall. In contrast, strain $\mathrm{N} 2^{\mathrm{T}}$ formed a loose, powdery ferric iron mineral. The other isolates were not further studied.

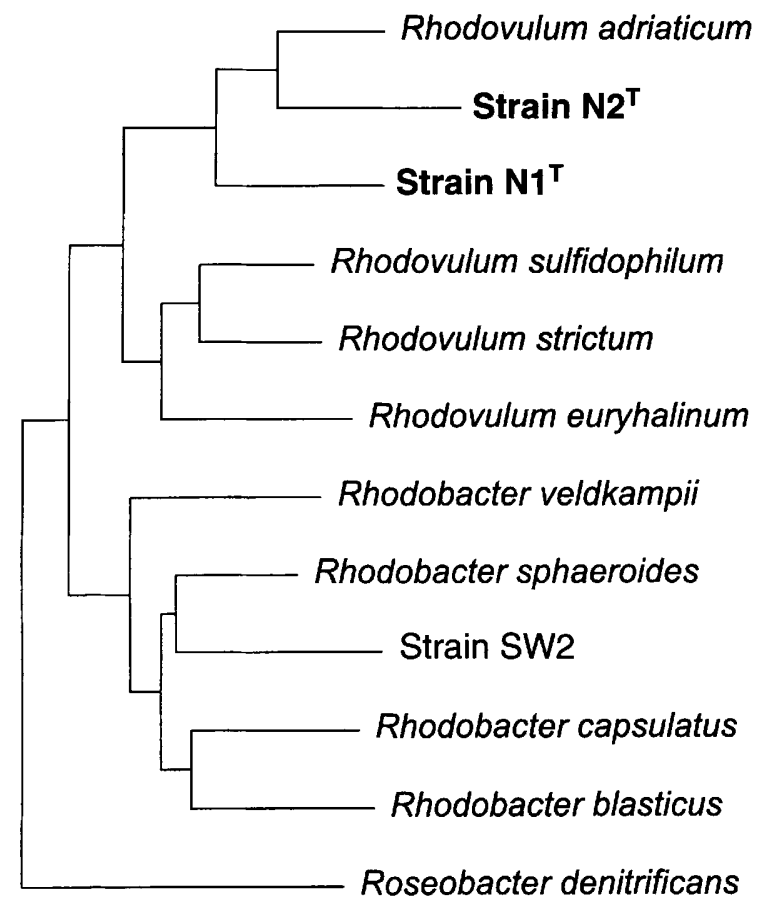

$5 \%$

Fig. 1. Dendrogram based on 165 rDNA sequence comparison indicating the position of strains $\mathrm{N}^{\top}$ and $\mathrm{N}^{\top}$ within the genus Rhodovulum. The genera Rhodovulum and Rhodobacter together form a major cluster within the $\alpha$ subclass of the Proteobacteria. The scale bar represents five nucleotide substitutions per 100 nucleotides.

\section{Correction of Rhodobacter blastica (sic)}

In the description of Rhodobacter blastica (sic) the name was incorrectly derived. The name is therefore corrected as follows: Rhodobacter blasticus corrig. [for Rhodobacter blastica (sic)]. The corrected name is used in this study.

\section{Phylogenetic affiliation and $\mathrm{G}+\mathrm{C}$ content of DNA}

Almost complete $16 \mathrm{~S}$ rDNA sequences of strains $\mathrm{N}^{\mathrm{T}}$ and $\mathrm{N} 2^{\mathrm{T}}$ comprising 1414 and 1415 nucleotides, respectively ( $>95 \%$ of the Escherichia coli sequence, positions 31-1519), were determined in this study. A total of 1034 nucleotides present in all of the strains between positions 47 and 1380 ( $E$. coli positions) were used in the phylogenetic analyses presented in Fig. 1. The phylogenetic dendrogram (Fig. 1) shows strains $\mathrm{N} 1^{\mathrm{T}}$ and $\mathrm{N} 2^{\mathrm{T}}$ to fall within the radiation of the genus Rhodovulum, which, along with the species of the genus Rhodobacter, forms a distinct cluster within the $\alpha$ subclass of the Proteobacteria (Hiraishi \& Ueda, 1994). The relationship of strains $\mathrm{N}^{\mathrm{T}}$ and $\mathrm{N} 2^{\mathrm{T}}$ to the species of the genus Rhodovulum is also seen from the $16 \mathrm{~S}$ rDNA sequence similarity values. The $16 \mathrm{~S}$ rDNA 
Table 1. Compounds tested as substrates for photoautotrophic or photoheterotrophic growth

+ , Utilized; -, not utilized; ND, no data.

\begin{tabular}{|c|c|c|c|c|c|c|}
\hline Compound & $\begin{array}{c}\text { Strain } \\
\text { N1 }^{\mathrm{T}}\end{array}$ & $\begin{array}{c}\text { Strain } \\
\mathrm{N} 2^{\mathrm{T}}\end{array}$ & $\begin{array}{c}\text { Rhodovulum } \\
\text { adriaticum* }\end{array}$ & $\begin{array}{l}\text { Rhodovulum } \\
\text { euryhalinum } \dagger\end{array}$ & $\begin{array}{c}\text { Rhodovulum } \\
\text { strictum }\end{array}$ & $\begin{array}{l}\text { Rhodovulum } \\
\text { sulfidophilum }\end{array}$ \\
\hline \multicolumn{7}{|l|}{ Inorganic } \\
\hline Hydrogen & + & + & - & ND & ND & + \\
\hline Sulfide & + & + & + & + & + & + \\
\hline Sulfite & - & - & ND & ND & ND & - \\
\hline Thiosulfate & + & + & + & + & + & + \\
\hline Sulfur & + & + & ND & ND & ND & + \\
\hline Ferrous iron & + & + & - & - & ND & - \\
\hline \multicolumn{7}{|l|}{ Organic } \\
\hline Formate & - & - & + & + & + & + \\
\hline Acetate & + & + & + & + & + & + \\
\hline Propionate & + & + & + & + & + & + \\
\hline Butyrate & + & - & - & + & + & + \\
\hline Valerate & + & - & + & + & + & + \\
\hline Caproate & - & - & + & ND & + & + \\
\hline Caprylate & - & - & ND & + & - & + \\
\hline Methanol & - & - & - & - & - & - \\
\hline Ethanol & - & - & + & + & - & - \\
\hline Pyruvate & + & + & + & + & + & + \\
\hline Lactate & + & + & + & + & + & + \\
\hline Succinate & + & + & + & + & + & + \\
\hline Fumarate & + & - & + & + & + & + \\
\hline Malate & + & + & + & + & + & + \\
\hline Citrate & - & - & - & - & + & - \\
\hline Benzoate & - & - & - & - & - & - \\
\hline Yeast extract & + & + & + & + & + & + \\
\hline Casamino acids & + & + & ND & + & + & + \\
\hline Aspartate & - & - & ND & + & - & - \\
\hline Cysteine & + & - & ND & ND & ND & ND \\
\hline Glutamate & + & + & ND & + & - & + \\
\hline Glucose & - & - & + & + & + & + \\
\hline Fructose & - & - & - & + & + & - \\
\hline Glycerol & - & + & + & + & - & + \\
\hline Mannitol & + & + & - & + & - & - \\
\hline
\end{tabular}

\footnotetext{
* Data from Neutzling et al. (1984).

$\dagger$ Data from Imhoff \& Trüper (1992)

+ Data from Hiraishi \& Ueda (1995).

$\S$ Data from Hansen \& Veldkamp (1973); Imhoff \& Trüper (1992).
}

sequences of strains $\mathrm{N}^{\mathrm{T}}$ and $\mathrm{N} 2^{\mathrm{T}}$ have similarity values in the range of $93 \cdot 6-94 \cdot 3 \%$ to species of the genus Rhodovulum while the sequence similarity to species of the genus Rhodobacter is lower and in the range of $90.9-92.9 \%$. Pairwise comparison of the $16 \mathrm{~S}$ rDNA sequences of strains $\mathrm{N1}^{\mathrm{T}}$ and $\mathrm{N} 2^{\mathrm{T}}$ shows them to share $95.2 \%$ similarity. One of the previously characterized ferrous-iron-oxidizing phototrophic bacteria, strain SW2, isolated from a freshwater habitat is affiliated with the genus Rhodobacter (Ehrenreich \& Widdel, 1994) and hence can be considered as a freshwater counterpart of strains $\mathrm{N}^{\mathrm{T}}$ and
$\mathrm{N} 2^{\mathrm{T}}$ within the $\alpha$ subclass. The $\mathrm{G}+\mathrm{C}$ content of strains $\mathrm{N} 1^{\mathrm{T}}$ and $\mathrm{N} 2^{\mathrm{T}}$ was 66 and $69 \mathrm{~mol} \%$, respectively, as determined by HPLC.

\section{Morphological features and photosynthetic pigments}

The cell morphology of both strains was influenced by the type of growth substrate. In photoheterotrophically grown cultures, cells of both strains were ovoid to rod-shaped and non-motile. Cells of strain $\mathrm{N}^{\mathrm{T}}$ were approximately $0.8 \times 2.4 \mu \mathrm{m}$ in size; cells of strain $\mathrm{N} 2^{\mathrm{T}}$ were slightly smaller with a mean size of 
$0.8 \times 1.6 \mu \mathrm{m}$. During growth on ferrous iron more elongated rod-shaped, non-motile cells (length up to $3.8 \mu \mathrm{m}$ ) prevailed. A similar influence of the substrate on cell morphology was reported for the ferrous-ironoxidizing, Rhodobacter-like freshwater strain SW2 (Ehrenreich, 1994).

When grown on ferrous iron, the brownish-orange colour of the ferric iron produced masked the colour of the cells. When grown photoheterotrophically, cultures of both strains were yellow-brown under strictly anoxic conditions and pink when the head space of the culture contained air. The photosynthetic pigments of the strains were bacteriochlorophyll $a$ and carotenoids of the spheroidene series (spheroidene, spheroidenone, hydroxyspheroidenone), as determined by HPLC. These are the characteristic photosynthetic pigments of Rhodovulum and Rhodobacter species (Imhoff \& Trüper, 1992).

\section{Physiological characterization}

Like all known Rhodovulum species (Hiraishi \& Ueda, 1994), the newly isolated strains also require $\mathrm{NaCl}$ for optimal growth. Strains $\mathrm{N}^{\mathrm{T}}$ and $\mathrm{N} 2^{\mathrm{T}}$ grew at $\mathrm{NaCl}$ concentrations of $20-70$ and $10-70 \mathrm{~g} \mathrm{l}^{-1}$, respectively. An $\mathrm{NaCl}$ concentration of 25-50 $\mathrm{g} \mathrm{l}^{-1}$ was optimal for both strains.

Photoautotrophic growth of strains $\mathrm{N} 1^{\mathrm{T}}$ and $\mathrm{N} 2^{\mathrm{T}}$ was tested with electron donors other than ferrous iron. Both strains utilized sulfide and thiosulfate, like all other known Rhodovulum species, and in addition were able to oxidize hydrogen and sulfur, like Rhodovulum sulfidophilum (Hansen \& Veldkamp, 1973; Hiraishi \& Ueda, 1995; Imhoff \& Trüper, 1992; Table 1). However, only strains $\mathrm{N} 1^{\mathrm{T}}$ and $\mathrm{N} 2^{\mathrm{T}}$ were able to oxidize ferrous iron (Table 1). Furthermore, both strains grew with iron sulfide, forming ferric iron and sulfate. The marine strains $\mathrm{N} 1^{\mathrm{T}}$ and $\mathrm{N} 2^{\mathrm{T}}$ share this capacity with the freshwater strains SW2 and L7, which also oxidized iron sulfide completely (Ehrenreich \& Widdel, 1994). However, the freshwater strains SW2 and L7 were unable to oxidize free sulfide, thiosulfate and elemental sulfur (Ehrenreich, 1994). Strains $\mathrm{N} 1^{\mathrm{T}}$ and $\mathrm{N} 2^{\mathrm{T}}$ grew photoheterotrophically on a variety of organic compounds (Table 1). The range of substrates utilized by strains $\mathrm{N}^{\mathrm{T}}$ and $\mathrm{N} 2^{\mathrm{T}}$ differed slightly; only strain $\mathrm{N} 1^{\mathrm{T}}$ grew with butyrate, valerate, fumarate or cysteine, and only strain $\mathrm{N} 2^{\mathrm{T}}$ utilized glycerol. Like all other known Rhodovulum species, the new strains grew well on acetate, lactate, malate, pyruvate, succinate, yeast extract and Casamino acids (Hiraishi \& Ueda, 1995; Imhoff \& Trüper, 1992; Table 1). On acetate, malate or Casamino acids, a doubling time of $11 \mathrm{~h}$ was measured. The capacity for chemotrophic, respiratory growth was tested with acetate as organic substrate. Strains $\mathrm{N} 1^{\mathrm{T}}$ and $\mathrm{N} 2^{\mathrm{T}}$ grew in the dark with oxygen as electron acceptor. Under anaerobic conditions in the dark, growth was not observed with nitrate, nitrite, DMSO or with trimethylamine- $N$-oxide. Recently it was

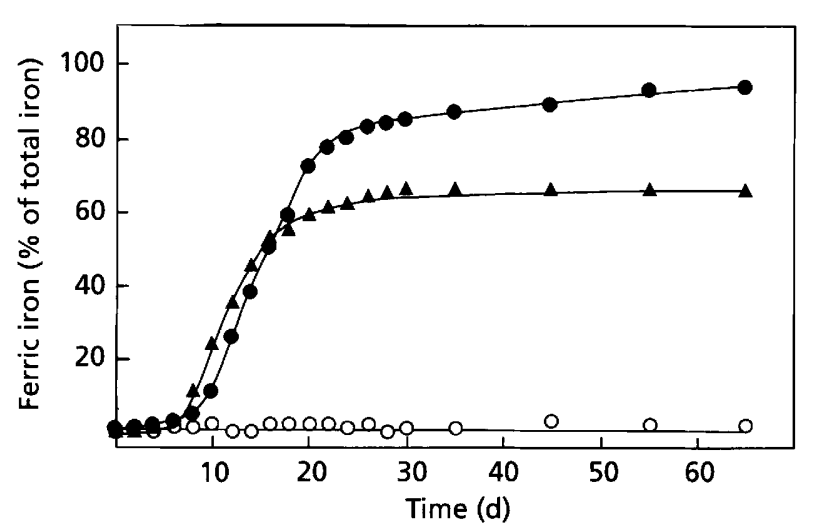

Fig. 2. Ferric iron production during photoautotrophic growth with $10 \mathrm{mM}$ ferrous iron. $\boldsymbol{A}$, Ferric iron in a growing culture of strain $\mathrm{N}^{\top}$; 0 , ferric iron in a growing culture of strain $\mathrm{N}^{\top} ; \mathrm{O}$, ferric iron in a pasteurized control with strain $\mathrm{N}^{\top}$.

reported that Rhodobacter capsulatus grew by dissimilatory reduction of ferric iron (Dobbin et al., 1996). However, none of the marine or freshwater ferrous-iron-oxidizing strains obtained so far was able to use ferric iron for dissimilatory growth in the dark (Ehrenreich, 1994; Heising \& Schink, 1998). Both strains did not grow fermentatively with yeast extract, Casamino acids, pyruvate or fumarate.

The $\mathrm{pH}$ range and optimum for growth depended on the substrate supplied. With acetate, both strains grew between $\mathrm{pH} 6$ and 9, with an optimum between $\mathrm{pH} 7$ and 7.3 for strain $\mathrm{N} 1^{\mathrm{T}}$, and an optimum between $\mathrm{pH} 7.3$ and 7.7 for strain N2 ${ }^{\mathrm{T}}$. However, growth with ferrous iron was for both strains only observed between pH 6.3 and 6.8 , with an optimum at $\mathrm{pH} 6.5$. Such a striking, narrow $\mathrm{pH}$ range and pronounced optimum in ferrous-iron-containing media was also observed with anaerobic denitrifying ferrous-ironoxidizing bacteria from freshwater sediments (Straub et al., 1996; K. L. Straub, unpublished results) and with aerobic ferrous-iron-oxidizing bacteria (Pringsheim, 1949). The temperature range for growth of both strains was between 10 and $35^{\circ} \mathrm{C}$, with an optimum at $20-25^{\circ} \mathrm{C}$ for strain $\mathrm{N1}^{\mathrm{T}}$ and an optimum at $25-28^{\circ} \mathrm{C}$ for strain $\mathrm{N} 2{ }^{\mathrm{T}}$. Both strains required biotin and nicotinate; strain $\mathrm{N} 2^{\mathrm{T}}$ also needed vitamin $\mathbf{B}_{12}$.

\section{Growth with ferrous iron}

The time courses of ferrous iron oxidation were different in cultures of the two strains (Fig. 2). In repeated growth experiments, strain $\mathrm{N}^{\mathrm{T}}$ always oxidized $60-70 \%$ of the ferrous iron within $15 \mathrm{~d}$, after a lag phase of $8 \mathrm{~d}$. During the same time, strain $\mathrm{N} 2^{\mathrm{T}}$ oxidized some $80 \%$ of the ferrous iron, and then the oxidation of ferrous iron proceeded slowly and finally reached more than $90 \%$. Also the freshwater isolates, strains SW2 and L7, oxidized ferrous iron almost 
completely (Ehrenreich \& Widdel, 1994). A greyishgreen intermediate oxidation state of iron, as observed in cultures of the freshwater strains (Ehrenreich \& Widdel, 1994), did not appear in the presently described marine cultures; in cultures of the latter, the white ferrous iron precipitates turned gradually into rusty-orange ferric iron precipitates. In strains $\mathrm{N}^{\mathrm{T}}$ and $\mathrm{N} 2^{\mathrm{T}}$, the ferric iron produced consisted of ferrihydrite (approx. 98\%) and traces of magnetite, as determined by electron diffraction analysis.

\section{Sulfur assimilation}

Since the enrichment culture depended on the presence of a reduced sulfur source, the sulfur requirement was again tested with the isolates. Strains $\mathrm{N}^{\mathrm{T}}$ and $\mathrm{N} 2^{\mathrm{T}}$ were grown photoheterotrophically with $10 \mathrm{mM}$ acetate and $0.5 \mathrm{mM}$ of various sulfur compounds. Growth in subcultures continued only in the presence of thiosulfate, elemental sulfur, sulfide or cysteine, but not with sulfate or sulfite. The same demand for reduced sulfur sources has been reported for the closely related Rhodovulum adriaticum (Neutzling et al., 1984). A possible toxic effect of sulfite was checked by growing the strains photoheterotrophically with $10 \mathrm{mM}$ acetate in the presence of different concentrations of sulfite $(0 \cdot 1-5 \mathrm{mM})$. At a sulfite concentration of $1 \mathrm{mM}$ and higher, growth of both strains was inhibited. Strain $\mathrm{N1}^{\mathrm{T}}$ was not only able to use cysteine as sulfur source, but also utilized cysteine (4 $\mathrm{mM}$ ) as the only substrate for photoheterotrophic growth (Table 1); sulfate was detected as the oxidation product. The capacity for photoheterotrophic growth on cysteine was for the first time reported for strain SiCys, classified as Rhodovulum sulfidophilum (Heising et al., 1996). However, strain SiCys is unable to oxidize ferrous iron (B. Schink, personal communication).

\section{Taxonomic conclusion}

The results of the 16S rDNA sequence determination and analyses place strains $\mathrm{N}^{\mathrm{T}}$ and $\mathrm{N} 2^{\mathrm{T}}$ within the radiation of the $\alpha$ subclass of the Proteobacteria and more precisely within the radiation of the species of the genus Rhodovulum. Although sharing the capacity for ferrous iron oxidation with strain SW2, the two strains are distinct from the previously described strain SW2, which is a member of the genus Rhodobacter (Ehrenreich \& Widdel, 1994).

On the basis of the low $16 \mathrm{~S}$ rDNA sequence similarity values $(<95 \%)$ to other species of the genus Rhodovulum and their distinct physiological characteristics when compared to other species of this genus, strains $\mathrm{N}^{\mathrm{T}}$ and $\mathrm{N} 2^{\mathrm{T}}$ represent novel species. Strains $\mathrm{N} 1^{\mathrm{T}}$ and $\mathrm{N} 2^{\mathrm{T}}$ can be differentiated from each other on the basis of their low 16S rDNA sequence similarity $(95.2 \%)$, the differing $\mathrm{G}+\mathrm{C}$ content of their DNA and the differences in the range of substrates used for growth. On the basis of these characteristics and the differences observed between the two strains, they are described as two new species of the genus Rhodovulum, Rhodovulum iodosum sp. nov., for strain $\mathrm{N1}^{\mathrm{T}}$, and Rhodovulum robiginosum $\mathrm{sp}$. nov., for strain $\mathrm{N} 2^{\text {T. }}$.

\section{Description of Rhodovulum iodosum sp. nov.}

Rhodovulum iodosum (i.o.do'sum. M.L. adj. from Gr. adj. iodaes violet, and also rusty, indicating the formation of rusty, ferric iron deposits during photoautotrophic growth on ferrous iron).

Ovoid to rod-shaped, non-motile cells, $0.5-0.8 \mu \mathrm{m}$ wide and $2 \cdot 4-3.8 \mu \mathrm{m}$ long. Multiplication by binary fission. Colour of strictly anaerobically grown cells is yellow-brown. Cells contain bacteriochlorophyll $a$ and carotenoids of the spheroidene series. Electron donors for photoautotrophic growth are hydrogen, sulfide, thiosulfate, elemental sulfur and ferrous iron; the main product of ferrous iron oxidation is ferrihydrite. Photoheterotrophic growth occurs with acetate, propionate, butyrate, valerate, pyruvate, lactate, succinate, fumarate, malate, cysteine, glutamate and mannitol. Grows chemoheterotrophically in the dark with oxygen. Optimal growth on ferrous iron occurs at $20-25^{\circ} \mathrm{C}, \mathrm{pH} 6 \cdot 5$, and with $25-50 \mathrm{~g} \mathrm{NaCl}^{-1}$. Growth is not possible with sulfate as sole sulfur source; thiosulfate, elemental sulfur, sulfide or cysteine is necessary as a source of reduced sulfur for cell synthesis. Biotin and nicotinate are required as growth factors. The $\mathrm{G}+\mathrm{C}$ content of the DNA is $66 \mathrm{~mol} \%$. The type strain, $\mathrm{N}^{\mathrm{T}}\left(=\mathrm{DSM} 12328^{\mathrm{T}}\right)$, was isolated from sediment of the mud flat of the Jadebusen, North Sea coast, Germany.

\section{Description of Rhodovulum robiginosum sp. nov.}

Rhodovulum robiginosum (ro.bi.gi.no'sum. L. adj. robiginosum, rusty, indicating the formation of rusty, ferric iron deposits during photoautotrophic growth on ferrous iron).

Ovoid to rod-shaped, non-motile cells, $0.5-0.8 \mu \mathrm{m}$ wide and $1 \cdot 6-3 \cdot 2 \mu \mathrm{m}$ long. Multiplication by binary fission. Colour of strictly anaerobically grown cells is yellow-brown. Cells contain bacteriochlorophyll $a$ and carotenoids of the spheroidene series. Electron donors for photoautotrophic growth are hydrogen, sulfide, thiosulfate, elemental sulfur and ferrous iron; the main product of ferrous iron oxidation is ferrihydrite. Photoheterotrophic growth occurs with acetate, propionate, pyruvate, lactate, succinate, malate, glutamate, glycerol and mannitol. Grows chemoheterotrophically in the dark with oxygen. Optimal growth on ferrous iron occurs at $25-28^{\circ} \mathrm{C}, \mathrm{pH} 6 \cdot 5$, and with $25-50 \mathrm{~g} \mathrm{NaCl} \mathrm{l}^{-1}$. Growth is not possible with sulfate as sole sulfur source; thiosulfate, elemental sulfur, sulfide or cysteine is necessary as a source of reduced sulfur for cell synthesis. Biotin, vitamin $B_{12}$ and nicotinate are required as growth factors. The $\mathrm{G}+\mathrm{C}$ content of the DNA is $69 \mathrm{~mol} \%$. The type strain, $\mathrm{N} 2^{\mathrm{T}}\left(=\mathrm{DSM} 12329^{\mathrm{T}}\right)$, was isolated from 


\section{ACKNOWLEDGEMENTS}

We thank Marianne Hanzlik from the Institut für Allgemeine und Angewandte Geophysik, Munich, Germany, for electron diffraction analysis. This work was supported by the Deutsche Forschungsgemeinschaft, the Fonds der Chemischen Industrie and the Max-PlanckGesellschaft.

\section{REFERENCES}

Aller, R. C., Mackin, J. E. \& Cox, R. T., Jr (1986). Diagenesis of Fe and $\mathrm{S}$ in Amazonian inner shelf muds: apparent dominance of $\mathrm{Fe}$ reduction and implications for the genesis of ironstones. Continental Shelf Res 6, 263-289.

Bak, F., Scheff, G. \& Jansen, K.-H. (1991). A rapid and sensitive ion chromatographic technique for the determination of sulfate and sulfate reduction rates in freshwater lake sediments. FEMS Microbiol Ecol 85, 23-30.

Brookins, D. G. (1988). Eh-pH Diagrams for Geochemistry. Berlin, Heidelberg \& New York: Springer.

Canfield, D. E., Jørgensen, B. B., Fossing, H. \& 7 other authors (1993a). Pathways of organic carbon oxidation in three continental margin sediments. Mar Geol 113, 27-40.

Canfield, D. E., Thamdrup, B. \& Hansen, J. W. (1993b). The anaerobic degradation of organic matter in Danish coastal sediments: iron reduction, manganese reduction and sulfate reduction. Geochim Cosmochim Acta 57, 3867-3883.

DeSoete, G. (1983). A least square algorithm for fitting additive trees to proximity data. Psychometrica 48, 621-626.

Dobbin, P. S., Warren, L. H., Cook, N. J., McEwan, A. G., Powell, A. K. \& Richardson, D. J. (1996). Dissimilatory iron(III) reduction by Rhodobacter capsulatus. Microbiology 142, 765-774.

Ehrenreich, A. (1994). Die anaerobe Oxidation von $F e(I I)$ durch Purpurbakterien. PhD thesis, University of Bremen.

Ehrenreich, A. \& Widdel, F. (1994). Anaerobic oxidation of ferrous iron by purple bacteria, a new type of phototrophic metabolism. Appl Environ Microbiol 60, 4517-4526.

Fachgruppe Wasserchemie, G. D. C. (1991). Deutsche Einheitsverfahren zur Wasser-, Abwasser- und SchlammUntersuchung (vol. Bd. II, E1). Weinheim: VCH.

Felsenstein, J. (1993). PHYLIP (phylogenetic inference package) version 3.5.1. Department of Genetics, University of Washington, Seattle, USA.

Hansen, T. A. \& Veldkamp, H. (1973). Rhodopseudomonas sulfidophila, nov. spec., a new species of the purple nonsulfur bacteria. Arch Microbiol 92, 45-58.

Heising, S. \& Schink, B. (1998). Phototrophic oxidation of ferrous iron by a Rhodomicrobium vannielii strain. Microbiology 144, 2263-2269.
Heising, S., Dilling, W., Schnell, S. \& Schink, B. (1996). Complete assimilation of cysteine by a newly isolated non-sulfur purple bacterium resembling Rhodovulum sulfidophilum (Rhodobacter sulfidophilus). Arch Microbiol 165, 397-401.

Hiraishi, A. \& Ueda, Y. (1994). Intrageneric structure of the genus Rhodobacter: transfer of Rhodobacter sulfidophilus and related marine species to the genus Rhodovulum gen. nov. Int $J$ Syst Bacteriol 44, 15-23.

Hiraishi, A. \& Ueda, Y. (1995). Isolation and characterization of Rhodovulum strictum sp. nov. and some other purple nonsulfur bacteria from colored blooms in tidal and seawater pools. Int $J$ Syst Bacteriol 45, 319-326.

Imhoff, J. F. \& Trüper, H. G. (1992). The genus Rhodospirillum and related genera. In The Prokaryotes, 2nd edn, pp. 2141-2155. Edited by A. Balows, H. G. Trüper, M. Dworkin, W. Harder \& K.-H. Schleifer. Berlin, Heidelberg \& New York: Springer.

Jukes, T. H. \& Cantor, C. R. (1969). Evolution of protein molecules. In Mammalian Protein Metabolism, pp. 21-132. Edited by H. N. Munro. New York: Academic Press.

Maidak, B. L., Larsen, N., McCaughey, M. J., Overbeek, R., Olsen, G. J., Fogel, K., Blandy, J. \& Woese, C. R. (1994). The Ribosomal Database Project. Nucleic Acids Res 22, 3485-3487.

Neutzling, O., Imhoff, J. F. \& Trüper, H. G. (1984). Rhodopseudomonas adriatica sp. nov., a new species of the Rhodospirillaceae, dependent on reduced sulfur compounds. Arch Microbiol 137, 256-261.

Overmann, J., Fischer, U. \& Pfennig, N. (1992). A new purple sulfur bacterium from saline littoral sediments, Thiorhodovibrio winogradskyi gen. nov. and sp. nov. Arch Microbiol 157, 329-335.

Pringsheim, E. G. (1949). Iron bacteria. Biol Rev 24, 200-245.

Rainey, F. A., Ward-Rainey, N., Kroppenstedt, R. M. \& Stackebrandt, E. (1996). The genus Nocardiopsis represents a phylogenetically coherent taxon and a distinct actinomycete lineage: proposal of Nocardiopsaceae fam. nov. Int J Syst Bacteriol 46, 1088-1092.

Straub, K. L., Benz, M., Schink, B. \& Widdel, F. (1996). Anaerobic, nitrate-dependent microbial oxidation of ferrous iron. Appl Environ Microbiol 62, 1458-1460.

Sun, M., Aller, R. C. \& Lee, C. (1991). Early diagenesis of chlorophyll-a in Long Island Sound sediments: a measure of carbon flux and particle reworking. J Mar Res 49, 379-401.

Thamdrup, B., Fossing, H. \& Jørgensen, B. B. (1994). Manganese, iron and sulfur cycling in a coastal marine sediment, Aarhus Bay, Denmark. Geochim Cosmochim Acta 58, 5115-5129.

Widdel, F. \& Bak, F. (1992). Gram-negative mesophilic sulfatereducing bacteria. In The Prokaryotes, 2 nd edn, pp. 3352-3378. Edited by A. Balows, H. G. Trüper, M. Dworkin, W. Harder \& K.-H. Schleifer. Berlin, Heidelberg \& New York: Springer

Widdel, F., Schnell, S., Heising, S., Ehrenreich, A., Assmus, B. \& Schink, B. (1993). Ferrous iron oxidation by anoxygenic phototrophic bacteria. Nature 362, 834-836. 